Boskovic, V., Stamatovic Vuckovic, S. (2020): Anti-evolution of the phenomenon of construction - Its relation to the environment. Agriculture and Forestry, 66 (4): 57-72.

DOI: 10.17707/AgricultForest.66.4.05

Vanja BOSKOVIĆ ${ }^{1}$, Slavica STAMATOVIĆ VUČKOVIĆ ${ }^{2}$

\title{
ANTI-EVOLUTION OF THE PHENOMENON OF CONSTRUCTION-ITS RELATION TO THE ENVIRONMENT
}

\section{SUMMARY}

The phenomenon of construction, as an act of creation of a man-builder in the landscapes, is being discussed in this paper. Vernacular architecture is the creation of the epochal relation of man to the environment. The coexistence of man and nature has been transformed into architecture that still goes beyond the reach of contemporary construction. Evolutionary processes have been called into question, which justifies the concern of the international community regarding the protection of the so-called cultural landscapes, places of conflict between nature and man. What is the perspective of these creations and are the builders of today familiar with the postulates and laws of creating the dwelling architecture of their predecessors? The paper elaborates general principles of protection and emphasizes the importance of preserving the rarity of the traditional opus of construction related to the local examples that exist on the territory of Montenegro, which are the works of an unknown builder and which are currently under-researched and under-valorised. The current knowledge base on "ambient nuclei" (Perovic, 2005) presented through the cases of villages in Montenegro does not grasp the complete essence of the architectural thought. Evolutionary processes of the permeation of natural processes with modus of construction and the current stagnation of processes demonstrated on the examples of villages Godinje and Gornja Brca, located on slopes not far from the water, have been considered in this paper. Man has affected the nature by the phenomenon of construction, creating the unique cultural landscapes. Man has used nature as a resource. The evolution of man in the natural environment implied the evolution of nature itself, natural processes flowed simultaneously. Balance is achieved through synergy. However, there was a point in time when nature continued its life without man, because natural forces have overpowered the human creation.

Keywords: evolution; creation; cultural landscape; dwelling; natural processes.

1 Vanja Boskovic (corresponding author: vanjaboofovaboskovic@gmail.com), Center for Conservation and Archeology of Montenegro. Master student of the University of Montenegro, Faculty of Architecture, Podgorica, MONTENEGRO.

2 Slavica Stamatovic Vuckovic, University of Montenegro, Faculty of Architecture, Podgorica, MONTENEGRO.

Paper presented at the GEA (Geo Eco-Eco Agro) International Conference 2020, Podgorica.

Notes: The authors declare that they have no conflicts of interest. Authorship Form signed online.

Received:28/10/2020

Accepted:05/12/2020 


\section{Introduction}

\section{Vernacular architecture as an act of creation by unknown man}

The topic of the paper is the reach of vernacular architecture, which is a reflection of man's aspiration to create conditions for existence in nature and to improve the conditions of his life by continually unconscious architecture. It is an unpretentious, "modest" architecture, without the urge to dominate the natural environment, based on human intuition. An architecture that adapts to the man and the natural environment, as a contrast to today's architecture, which tends to dominate nature.

The paper will focus on the achievements of vernacular architecture in the territory of Montenegro. The study of the phenomenon of vernacular architecture is based on the examples of the Montenegrin villages of Godinje and Gornja Brca. The thread connecting these two places is the uniqueness of the cultural landscape and the response of the unknown man-builder to the established natural context. The natural context of Godinje and Gornja Brca is similar; both are positioned on a slope and close to the water, seen as a source of life. The builder's response is also unique; both "ambient nuclei" have the views of the lake or the sea, but at the same time they are distanced from the water for easier defence against the enemy. The aim of the research is to define certain principles and postulates in the process of construction - the creation of vernacular architecture. Can postulates of vernacular architecture be implemented by modern architects when creating?

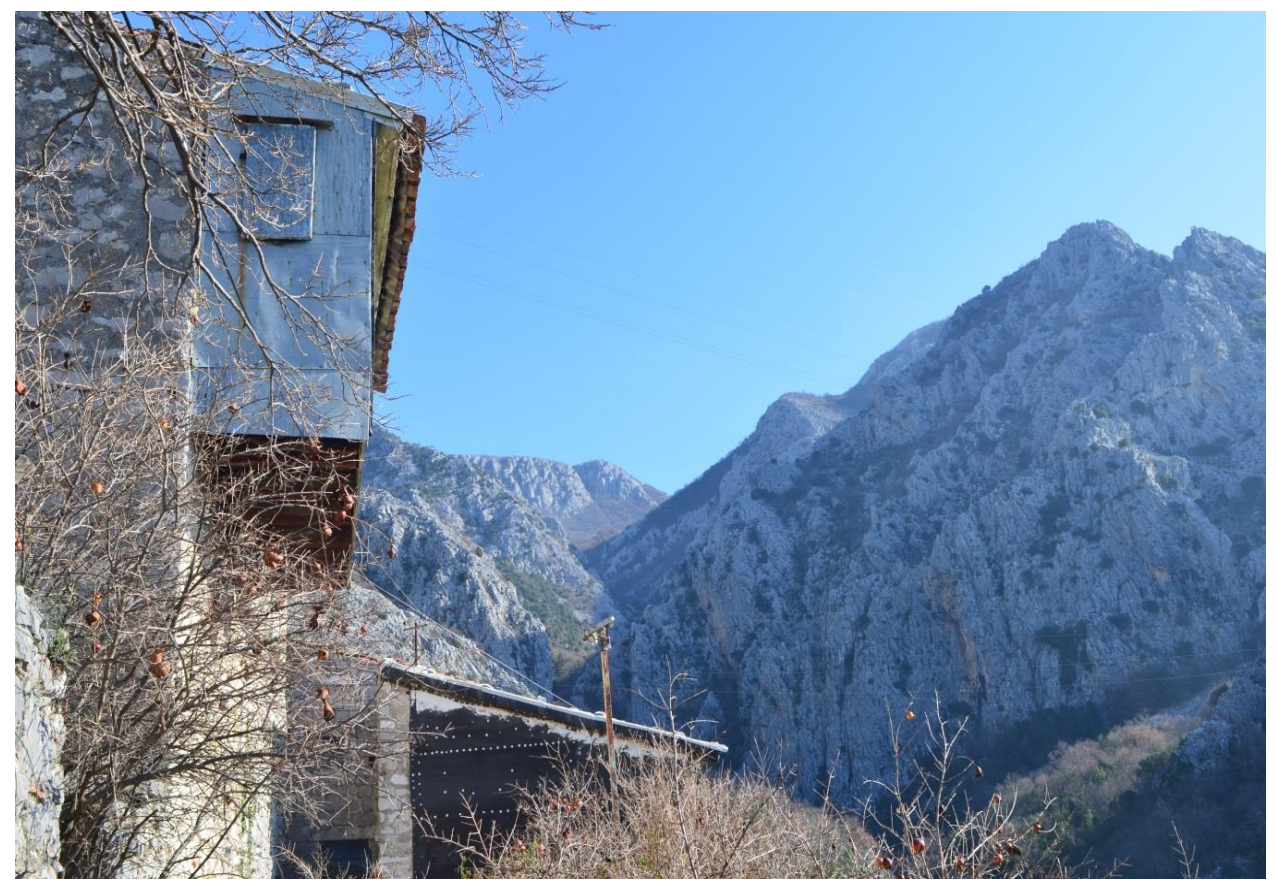

Figure 1. Cultural landscape, village Gornja Brca 
The etymology of the concept of vernacular architecture is interpreted by Darko Radovic and is linked to Roman law in which the term vernacular denotes the opposite of the goods being purchased. Vernacular is a Latin word and its basic sense refers to "A slave born in my house by a slave whom I own" (Radovic, 2005). Radovic also quotes the Roman grammarian Vara, who, by the term vernacular means indigenous words.

In his book Architecture without architects, Rudofsky Bernard defines vernacular architecture as a timeless creation that does not pass through the fashion cycles and which, above all, satisfies the basic human need for space, adding that: "As a rule, the origins of indigenous building forms and constructive methods is lost and represents a part distant past. Buried below typical Mediterranean houses". (Rudofsky, 1985).

Vernacular architecture is a product of spontaneity and intuition; it is not the answer of a thoughtful architectural approach of an architect, driven by the knowledge of the theory of architecture, urbanism, and psychology of perception, with an understanding of the law of the unity. The question then arises as to how the ambient entities were then interpolated into landscapes. Who is their builder?

The answer may also be found in Le Corbusier's "story from the east" about the art of the villagers, who create traditional art embodied in a vase form. Describing vases, Le Corbusier speaks of a person's innate aesthetic sense to connect line, colour, abstract performances, aesthetic values, and unconsciously create a work of art, relying on the inner intuition and creative force that exists in each person, as well as the innate sense of harmony, because in the end, man himself is a product of natural harmony, "The peasants' art is an astonishing creation of aesthetic sensuality." (Le Corbusier, 2008)

If we would talk about successful architecture of peasants, we would find a certain principle in the method of multiplication, a certain repetition of the adopted model of a house for a certain environment, whereby the thinking manbuilder would notice the defects of a certain model and during the next construction he would eliminate the deficiencies and refine the model until he unconsciously reaches the level of architectural realization, striving exclusively to creating a safe existential space. On the other hand, out of the need for less expenditure, he thoughtfully used the natural context and ambience. Dom Hans van der Laan will, regarding the aforementioned house-context relation, say that the house is the place of our encounter with nature, that it is actually a "slice of living space that we extract from the natural environment by constructing the walls". (Dom Hans van der Laan, 2009)

However, today's relation between the man and the nature is characterized by the endeavour of man to master the nature, to subjugate it, to show, by the work which he creates, superiority over it. The paradigm of today is "Architecture - the ultimate victory over nature." Even in cases where the work follows the postulates of organic architecture, it still reflects man's triumph over nature and its inferiority, when the builder exploits and uncritically consumes natural resources; he usurps sites with attractive natural and cultural characteristics. 


\section{The act of building - about the nature of things Who builds houses, is it just a "homo- aedificator?"}

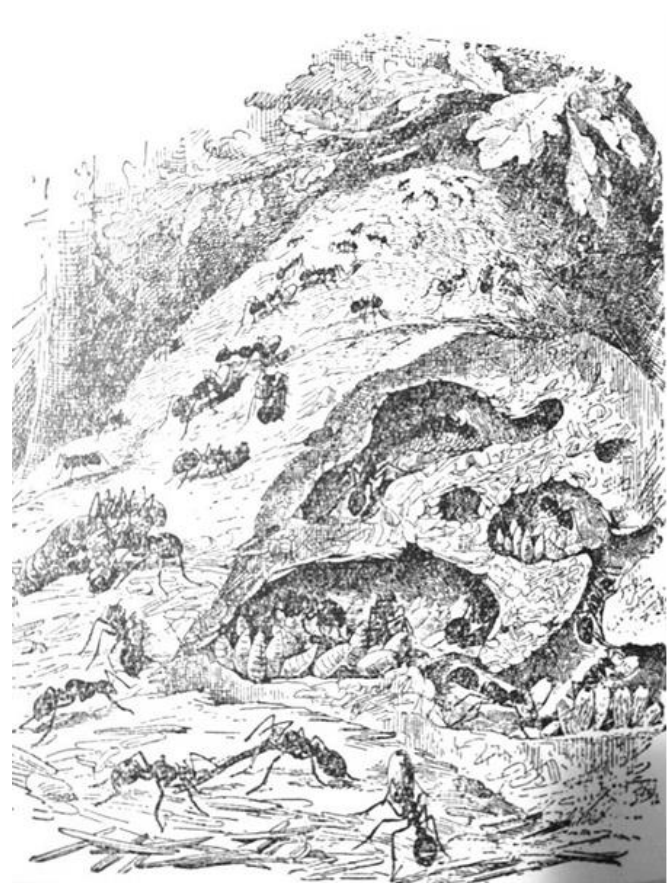

Figure 2. Anthill- ants construction*

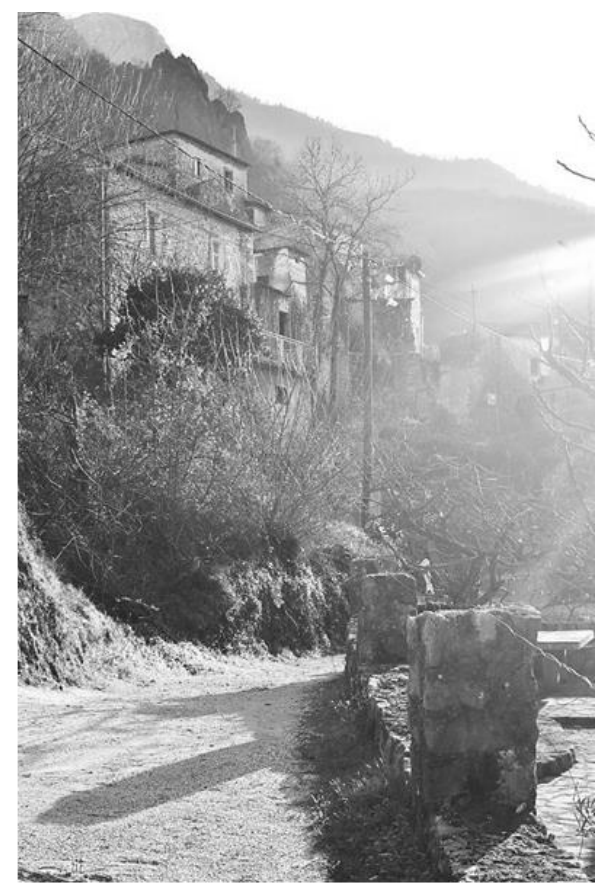

Figure 3. Godinje - man's construction * From the book of Pađan, Z. (2005): Arhitektura prirode, Zagreb, Školska knjiga

In rural areas, the land has ultimate ecological, social and cultural value (Kosanovic et al, 2016). In agrarian landscape, the need to study nature and culture together is evident (Palang et al., 2006). The patterns humans impose on the earth, purposefully as well as inadvertently, through land-use change are fundamental determinants of local, regional, and global ecological processes that ultimately influence the sustainability of both biological and cultural landscapes, and thus human quality of life. (Redman, 2008; Fikfak. et al., 2017; Parsipour et al., 2019).

In the book by Zvonko Pađan, Architecture of Nature, the problem of the act of creating living spaces from prokaryotes to chimpanzees, that is, from organisms without a functional nucleus to organisms that are at the very top of evolutionary development, is meticulously discussed. On that occasion, Padan will conclude that there is a construction that develops independently of the human construction. With this in mind, the act of construction was not invented by man; construction also exists outside the human community. The essence of construction is the motive of construction, being in harmony with the environment and creating an inner existential space. However, in his exhaustive research, the Croatian architect and scientist did not conclude it with a full stop and he left space for further research on the evolutionary process of construction. 
The motive behind the construction is to provide the aspect of safety and comfort elements. Being intermittent with the environment means at the same time enclosing it to create a safe interior space, in which case the construction is based on the principles of biomimicry. Biomimicry involves incorporation of form, materialization and colour into the existing landscape.

Man's construction oeuvre stands out because he possesses an artistic line and does not merely satisfy the needs of existence. Man builds from his cultural and spiritual initiatives and thus stands out as the higher life form on Earth. In his research, Pađan will distinguish the construction of man and lower beings by saying: "While in the lower beings a narrow, genetic, hermetic program prevails, in a man's case, it is an open act of creation." (Pađan, 2005)

However, there is an order of builders in the human community as well. Vitruvius described the architect, the first builder, focusing on his education with the words: "He must still be adept at pen and drawing, he must have a good understanding of geometry, and know history well, to listen to philosophers diligently, to know music, to not be ignorant in medicine either, understands legal issues, and knows something about astronomy and the laws of heaven." Only after studying these scientific areas did the builder reach the "holy ground of architecture". (Vitruvius, 2009)

Examples of human construction, which are discussed further in the paper, are exceptions where Vitruvius' view on the education of an architect is not valid. We shall observe the act of construction as a genetic program that develops inside of a man, and what sets man's construction process apart from other builders is the innate aesthetic thought and awareness of the possible controlled use of the natural resources of the environment.

\section{From general to regional- International systems for protection and valorisation of cultural landscapes}

A series of photographs by Bernard Rudofky at the Museum of Modern Art in New York had marked the year of 1964. It was the autumn when Architecture without an Architect intrigued the expert public and provoked numerous polemics on the relationship of today's builders to the environment. An overview of the international scene and the existence of vernacular structures outside the territory of Montenegro will emphasize common principles of construction in the natural environment and the primacy of strategic protection of them. The cases of villages of Godinje and Brca will find an analogy with Italian towns settled on the slopes - Italian hill town, with the vernacular architecture of Apanomeria, a remarkable example where nature stimulated human creative power - classical vernacular and with the precursor of bioclimatic urbanism, the covered streets of cities in Spain and the Libyan Desert - covered streets.

By analyzing the above examples, we can conclude that the reach of vernacular architecture is timeless and extraterritorial, that the principles, ideas and thought underlying the vernacular architecture are general, and refined and materialized depending on the context. 
Considering the architectural heritage of vernacular architecture and landscapes as significant, numerous international conventions address the issues of their protection and valorisation, emphasizing the importance of integral protection and increasingly emphasizing the importance of cultural landscapes.

The recommendation on the protection of historical and traditional entities and their role in contemporary life defines the concepts of environment and protection. "The environment" of historical or traditional entities means a natural or constructed framework that influences the static and dynamic perception of these entities or is directly related to them in space, that is, natural, social or cultural connections. "Protection" means the identification, protection, conservation, restoration, rehabilitation, maintenance and revitalization of historical and traditional entities and their surroundings." (Nairobi, November 1976).

The Convention for the Protection of the Architectural Heritage of Europe defines "localities as common works of a man and nature, or areas partly built and sufficiently distinctive and homogeneous" as the architectural heritage (Granada, October 1985).

European Convention on the Landscape of the Council of Europe "Landscape is defined as a specific territory, as viewed by the population, whose character is the result of the actions and interactions of natural and / or anthropogenic factors." (Florence, October 2000). According to the definition formulated by UNESCO, "Landscape cultures are a combination of the effects of nature and man and illustrate the development of human society and its settlements over time under the influence of physical forces and / or the opportunities that represented their both external and an internal environment affected by social, economic and cultural forces. "

The Council of Europe Framework Convention on the value of cultural heritage for society introduces the concept of a common European heritage, consisting of "all forms of cultural heritage in Europe which collectively form a common source of memory, understanding, identity, cohesion as well as ideals, principles, values derived from the lessons learned during the progress and conflicts in the past." (Faro, October 2005).

Since the architectural heritage of the traditional relationship between architecture and landscapes in the Mediterranean area is very characteristic, the Euro-Mediterranean Charter was adopted in Rome in 2002 on the integrative valorisation of cultural heritage, relying on the historical and geographical link between the Mediterranean heritage and emphasizing the importance of establishing a new cultural heritage management strategy based on integrative planning.

Indigenous building forms and constructive methods therefore were not lost under the Mediterranean houses. Their values are recognized, internationally recognized, with the intention of upgrading Euro-Mediterranean identity with the goal of planned tourism development through comprehensive planning and valorisation. The Mediterranean House is still recognized today as a par excellence example of construction in the natural environment of the Mediterranean, where sea, stone and vegetation stimulate creativity during the act of construction. 


\section{From regional to local - National systems for protection and valorisation of cultural landscapes}

There is significant number of examples of vernacular architecture in the territory of Montenegro in areas with outstanding natural values. The synergy of a man-builder and nature has produced in the territory of only $13,812 \mathrm{~km}^{2}$ a variety of cultural landscapes on a scale from Mediterranean to mountain, Dinaric Alps in the north of Montenegro.

The Spatial Plan of Montenegro until 2020, which was adopted in 2008, recognizes 21 landscape unit, and the Skadar Lake area is one of them, where Godinje is also located (Ljeskovic, Mitrovic, 2012). While Gornja Brca is located between Bar and Sutomore, not far from the sea coast. Montenegro also ratified the European Landscape Convention in 2008, when it set out to implement the convention at a national level, recognizing the importance of protecting, managing and planning landscapes at national and interstate levels. (Kujundzic and Stamatovic Vuckovic, 2019)

The laws and strategies governing the protection of cultural landscapes at the national level are: Law on Spatial Planning and Construction of Facilities ("Official Gazette of Montenegro", No. 064/17 of 06.10.2017, 044/18 of 06.07.2018, 063/18 of 28.09 .2018); Law on the Marine Property ("Official Gazette of the Republic of Montenegro", Nos. 14/92, 59/92 and 27/94, Official Gazette of Montenegro ", Nos. 51/08, 21/09, 73/10 and 40/11); Law on Nature Conservation ("Official Gazette of Montenegro", No. 054/16 of 15.08.2016); Law on Protection of Cultural Property ("Official Gazette of Montenegro", No. 049/10 of 13.08.2010, 040 / 11 of 08.08.2011, 044/17 of 06.07.2017, 018/19 of 22.03.2019); National Sustainable Development Strategy until 2030 and a number of other laws and by-laws that tangent to the field of protection of cultural landscapes. Protection system is, in theory, based on the networking of complementary laws.

We can see Montenegro's tendency to establish effective, adapted and focused legislation on the issues of integral protection and connection of architectural heritage with spatial planning, which will avoid secular access to cultural heritage and utter commercialization of cultural heritage, while simultaneously giving life to cultural and natural resources. The protection of the cultural landscape and its integration for tourism purposes is a challenge for both citizens and competent national authorities.

The work program of the Government of Montenegro for 2011 envisaged and implemented the reform of cultural institutions dealing with the protection of cultural property into a new, as stated by the legal act - oriented, institutional framework, which is based on the sustainable use of cultural heritage. In order to successfully valorise cultural heritage, the need for a thoughtful revitalization of the architectural heritage space is increasingly emphasized, giving it a purpose that suits the needs of modern man. Only spaces and environments with recognized values can become the framework for contemporary lifestyles and the context of contemporary construction. In this way, the Ministry of Culture with 
the protection services, also contributes to the establishment of national guidelines for the development of architecture, giving context to contemporary architecture.

Finding a universal solution to the problem of revitalizing the architectural heritage of vernacular architecture and deus ex machina is not possible. Each cultural landscape carries with it certain social, cultural and natural peculiarities and complexities, which first must be noticed and analysed.

\subsection{Village Godinje - the coexistence of man and nature}

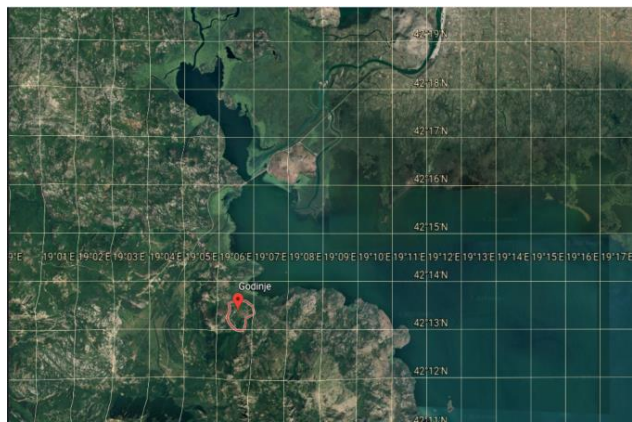

Figure 4. Location of the Godinje

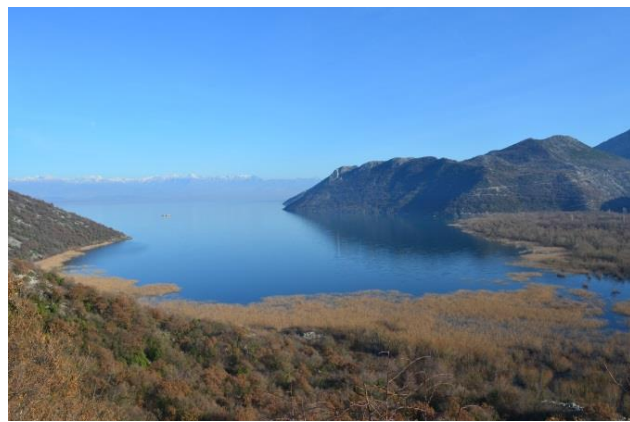

Figure 5. A view of Skadar Lake

"Then move on to another house - two children have appeared. Then you need to accommodate four children. As all this is very difficult, first draw a straight line around which you will build all the necessary units in the proper order, each on the smallest possible surface. Then, as in the form of a genealogy, figure out where they shall be, by arranging the corresponding units one after the other."(Le Corbusier, 2009).

The ambient unit of Godinje acquired the status of cultural property in early 2016. The image of a medieval town from the late XIV century, near Lake Skadar, is now made up of walls, traces of matrices and once dominant structures, partly preserved in their authentic form.

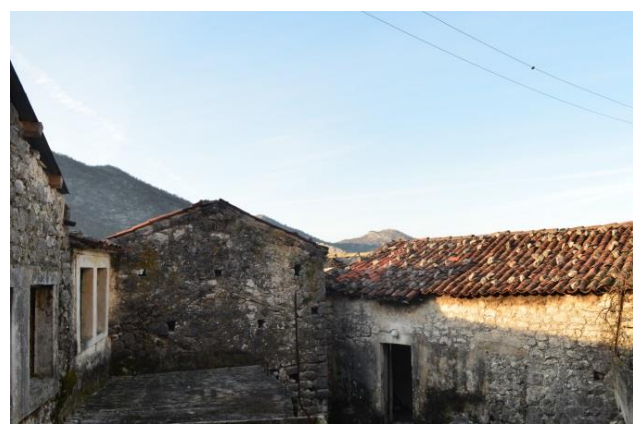

Figure 6. Roofs in village Godinje

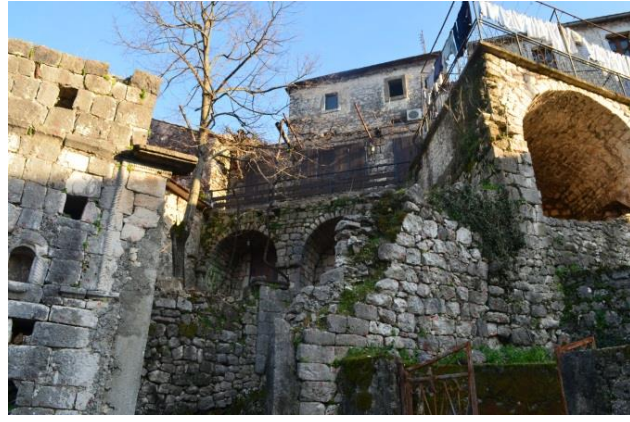

Figure 7. Architectural remains of village Godinje 
The identity of the place is contained in the unique colour, landscape and architectural style elements, which represent inherited values and are recognized as such, with a tendency to be nurtured and protected. Group forms of ambient nucleus houses remind us of a previous way of life and represent a kind of openair museums, in which the main exhibits are works of vernacular architecture, by the unknown man-builders. Several households still live in Godinje today, while the largest migration occurred after the devastating 1979 earthquake.

Godinje is located on a limestone hill not far from Skadar Lake with a clear view of the lake itself, while the village is impossible to be seen from the lake. It represents a settlement of the Lekovic fraternity, where the houses are positioned in the form of genealogies, stacked on top of one another. Natural and anthropogenic factors competed in this cultural landscape. The houses functionally and content-wise represent a combination of place of residence and economic space for storing food, making wine, conditioned by the configuration of the terrain and leaning on each other. The vine is the light motif of Godinje.

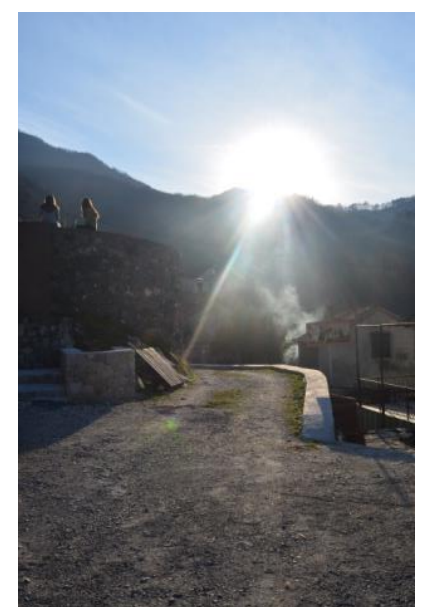

Figure 8. Gumno

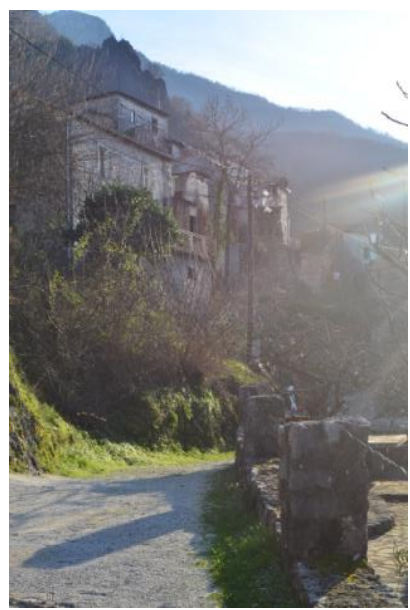

Figure 9. Dwellings

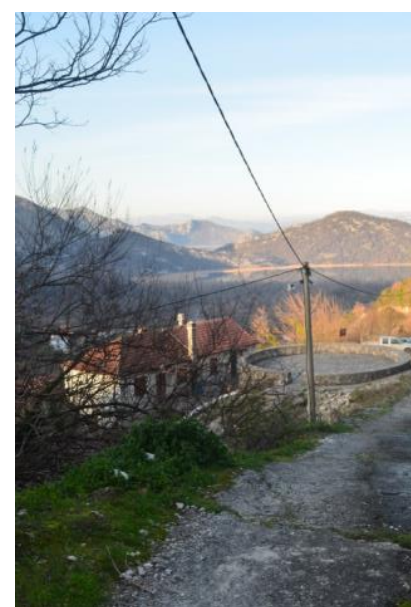

Figure 10. Center

To the Godinje ambient nucleus can be given the epitome of urban, primarily because of the present collectivism, the tightness of houses, clear paths, and the gathering place in the form of two outdoor threshing floors, which can replace the city squares. The larger threshing floor, the main square, has a symbolic significance for the locals in the hamlet; it is an intersection - three points, the intersection of three paths, which are parallel to the isohypses. All three come out to the stream, which houses the mills and wheels from which the hamlet was supplied with water.

If we were to analyze the house of Godinje as the basic unit of the settlement-archetype, in our perceptual field we would first find a volt, a stonevaulted semi-open space, as the most characteristic element of a house of Godinje. At the volt there are terraces, intimate open spaces over which one enters the house. The stone houses are covered with gable roof covered with 
hollow tiles. There are still under-researched assumptions about secret underground passageways linking houses.

The architecture, which dwelt as a genealogy following the isohypse, interpolated into the distinctive landscape of the limestone massif, using stone as the main form of materialization and natural rock as its support. The nucleus' distinctiveness speaks of a building evolution in solving the problem of construction in the sloping terrain. The inner courtyards are designed meaningfully and represent valuable sub-environments. On the facades of houses, the boundaries of the natural and anthropogenic are incomprehensible.

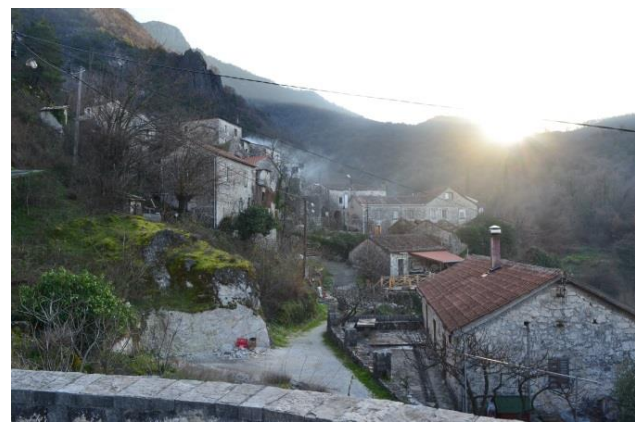

Figure 11. View from the "square"

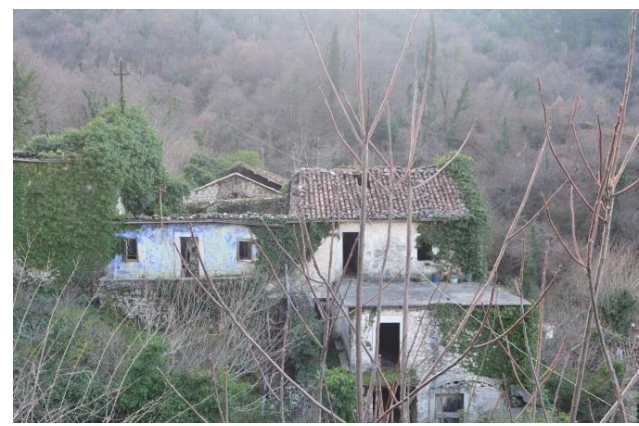

Figure 12. Community

Architect theorist Schulz would say that a man "builds what he sees." (Schultz, 2009) Further explaining that man represents his view of nature by construction. During construction, man follows the lines of nature and paths and has the need to translate the experienced meaning of nature and himself in nature into a building. Schultz talks about man's need to accumulate all the experienced meanings to create his own imago mundi, or microcosm. In this way, artificial places are created in the landscapes, as a concretization of man's view of the natural environment.

In Godinje, the air currents smell of the sea, which is mixed with the smell of lake fish, the dominant sound is the murmur of water, which comes from the local faucet, where the locals traditionally clean the fish, there are also rhythmic noises, which are occasionally heard and the silence, which originally comes from the arched volts, echoes through the narrow stairs and passageways, eventually sinking into the stone. It's always cold out there. It's a place known for its wine taste.

However, the phenomenon of construction has stagnated at some point. In pervading natural processes, nature has conquered the man. Man did not respond to nature's reaction to construction. He deviated from the principles of construction and utilitarianism became the main feature of his construction.

In the absence of an answer, the phenomenon of construction has become a destructive act, leaving behind the lasting devastation of the environment. The spatial values of the architecture of that time remained meaningless, devoid of function. 


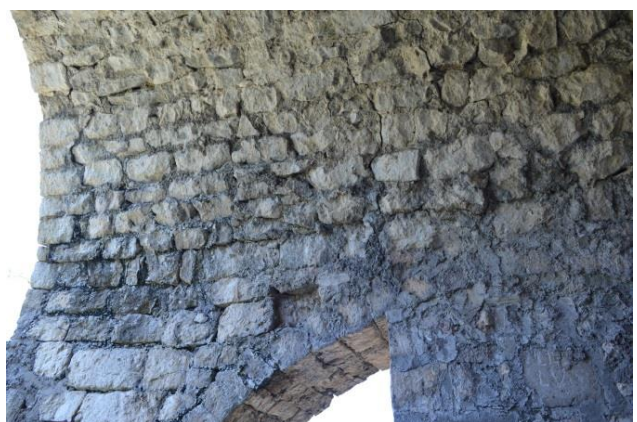

Figure 13. Arch, today

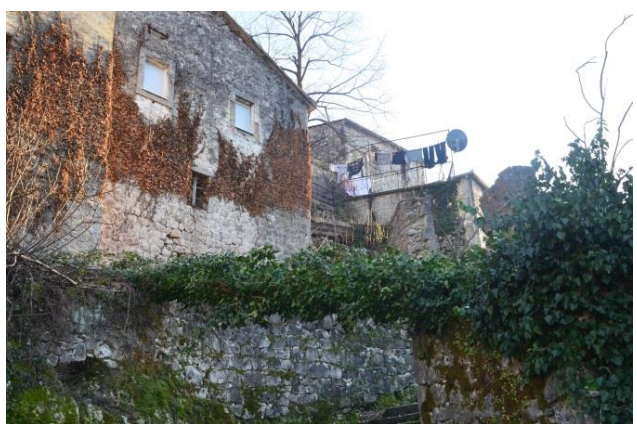

Figure 14. The power of nature

Some of the basic features of vernacular architecture have been lost. Architecture that seeks to rest on traditional construction is based on imitation. An essential feature of a "healthy" relationship with the environment is lost beneath the old house of Godinje, which remains as a reminder of the act of creation of unknown men-builder. The process of evolution stopped when man decided to wall up half of the arch.

\subsection{Gornja Brca village - coexistence of architecture and nature}

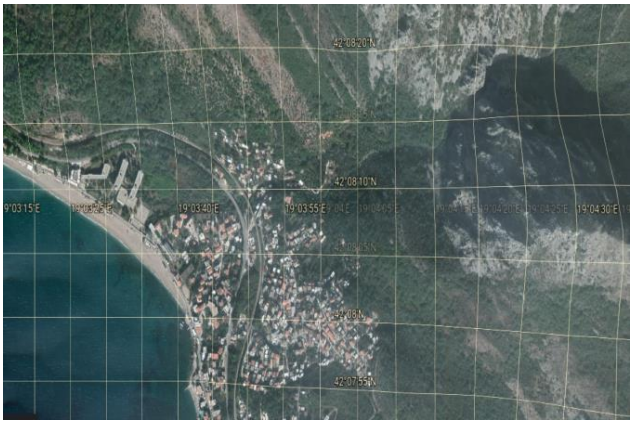

Figure 15 Location, Gornja Brca

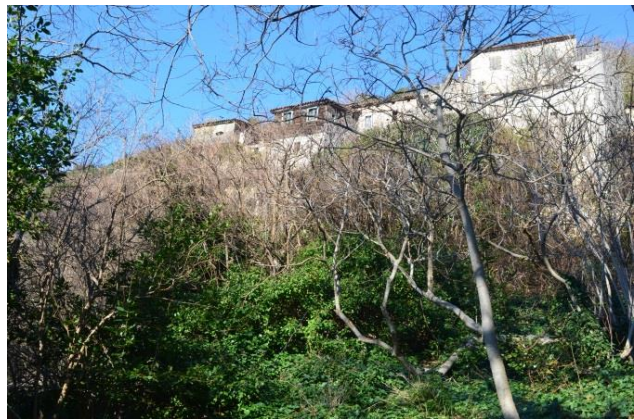

Figure 16. Village Gornja Brca

"The boundaries of the built-up space are known as floor, wall and ceiling. The boundaries of the landscape are structurally similar and consist of earth, horizontal and sky." (Le Corbusier, 2009)

Unlike Godinje, Gornja Brca is not a legally protected environment. In the Study on the Protection of Cultural Property, made for the purpose of developing the Special Purpose Spatial Plan for the coastal area of Montenegro, Gornja Brca was recognized as a good with recorded cultural values.

The village of Gornja Brca is located on a slope in the hinterland, not far from the sea. The background of this village is made of a rocky area. The site was often attacked, so fortification largely conditioned the conception of ambient nucleus development. Searching for a safe habitat, the settlement is located off the fertile foothills and the view to it is impossible from the sea. Today it is an 
uninhabited place because the locals have returned to the foothills of the hills, which abound in water and which today is an olive field. Olive is the light motif of Brca.

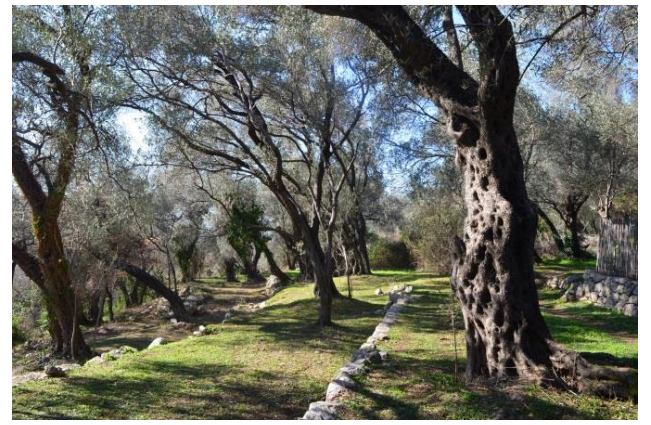

Figure 17. Olive grove

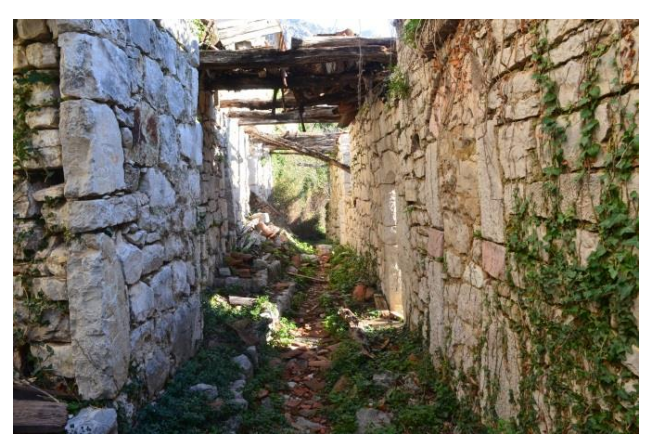

Figure 17. Covered street, Gornja Brca

Urbanism of the ambient unit is conditioned by the configuration of the terrain; the houses are built in a row with common gable walls. A number of houses were created following the development of the family as in Godinje. The houses have southern exposure and follow isohypses, with a pronounced horizontal, which represents nature. A characteristic architectural element is the "covered street", the beginning of bioclimatic urbanism. (Vuksanovic, 1998) The outlines of fortification architecture are observed in the conception of the ambient unit and in the examples of watch-towers with a pronounced vertical, a reflection of human construction.

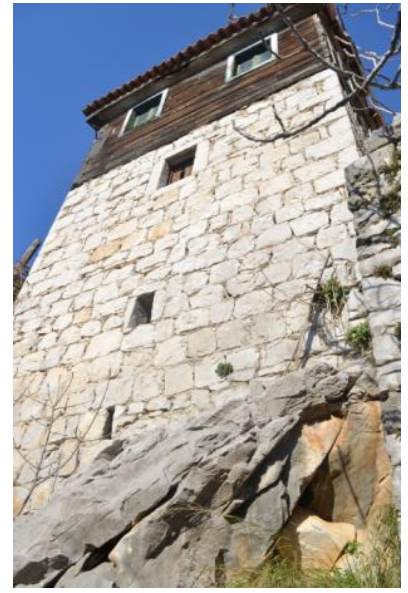

Figure 19.

Materialization

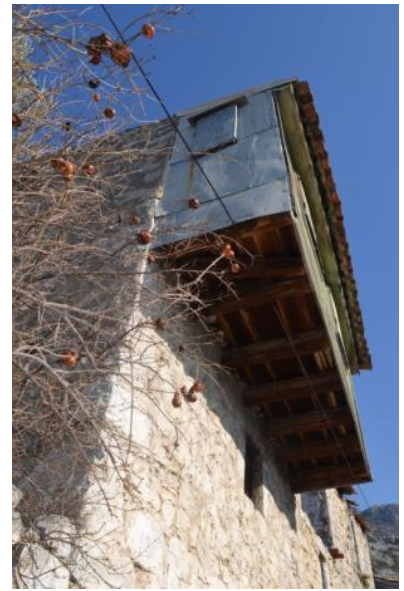

Figure 20.

Console

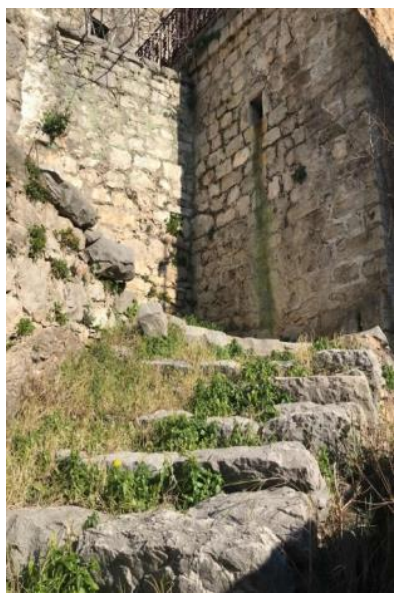

Figure 21.

Pathway in Gornja Brca

The house in Gornja Brca has a single-sloped roof, which follows the slope, like houses in Pastrovici and a stone plinth with a floor frequently materialized with timber. The families who have their roots in this place are 
Ilickovic, Luksic and Đuranovic. According to the chronicler, the village belongs to extremely old settlements. (Dudic, 1967)

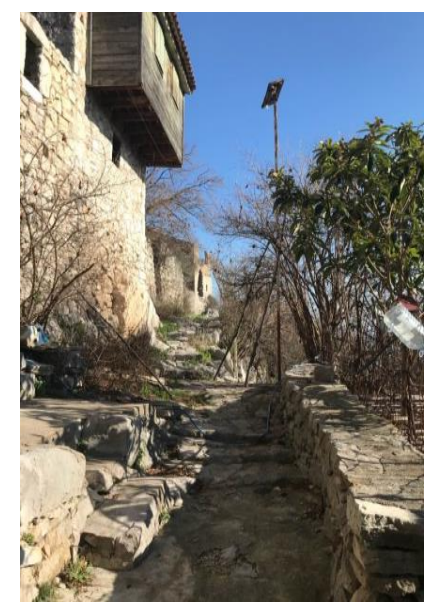

Figure 22.

Detail of single roof

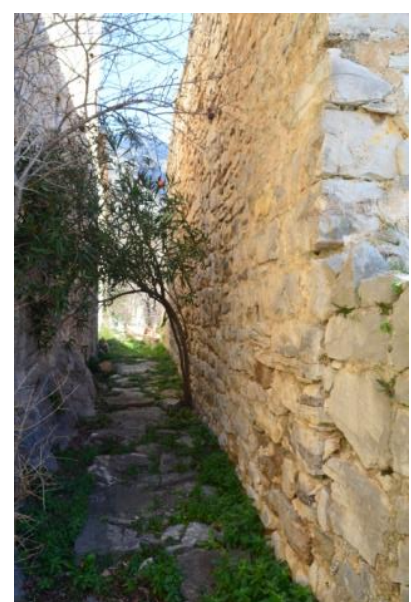

Figure 23.

In between

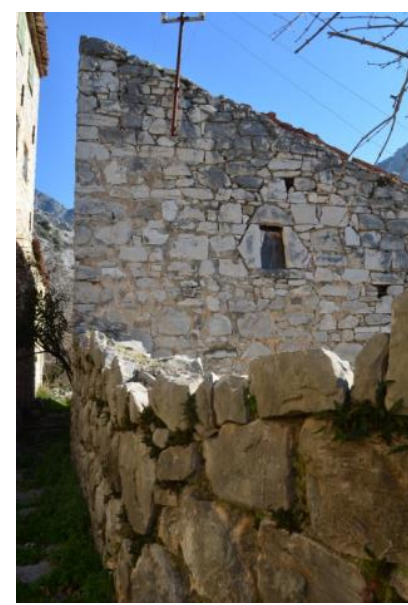

Figure 24. Detail of console in Gornja Brca

Reminiscence of the old settlement, situated on inaccessible terrain with the intention of being easily defended and inaccessible, now consists of stone walls with tree floors and green details in the form of creepers, which complete the picturesque picture of the settlement, as well as the dominant structures of the tower houses, pronounced cultural layering and spontaneity of construction. Unlike Godinje, Brca is dominated by the smell of the sea, blue colour, karst and wood, which gives the whole picture warmth. It is warm here, noises do not exist, only the voices and sounds of construction machinery from the village at the foot of the hill. As you approach the village, the sound you are recording is a rush of spring water from which the city water supply is supplied. In the memory of the visitor remains a view of the village covered with a shadow of the olive trees. Olives and pomegranates are everywhere; they have also shot up in the covered aisles, closing them. Rock, stone, vegetation, wood spontaneously change on the building. Recent interventions with brick, concrete and subsequently closed openings are also noticeable, again indicating a recent human existence. Now the walls of these houses are lifeless architecture and a mere remembrance of their former existence within the ambient nucleus.

In the example of the village of Gornja Brca, we can see the process of supplementing, upgrading; where man was left unfinished in his creative expression; he was replaced by nature, pomegranate shoot up. Brca is a reminder that stagnation is followed by disappearance; existence is only possible through constant evolutionary processes. The layering of Brca testifies to the man's effort to prolong his existence. After a while, man leaves architecture on a slope, forming existential conditions in a flat, fertile land, as the defence ceases to be a sine qua non. 
When the man stops building in space, nature continues its process and masters the man's construction, it settles there.

In her article, Professor Stamatovic Vuckovic defined Gornja Brca as "zero space". By the term "zero space", the professor refers to spaces that bring us back to zero, to the essence of our existence, an essence that is reflected in the synergistic relationship between nature and man. In these spaces one feels a strong connection with nature. The "zero space" returns a man to the beginning and reminds us that it is necessary to reprogram human construction to the primary postulates of construction in harmony with nature. (Stamatovic Vuckovic, 2018)

\section{Concluding Remarks Nullus rogandi finis}

Group forms of houses of ambient units, different from the built urban patterns, set to rural areas; created in natural landscapes, have succeeded in developing an honest relationship towards the ambient environment and nature (Fikfak, et al., 2015).

The unknown man-builder was able to create the conditions for existence on an inadequate space, creating authentic modules for shaping space through spontaneity as an allegory of nature.

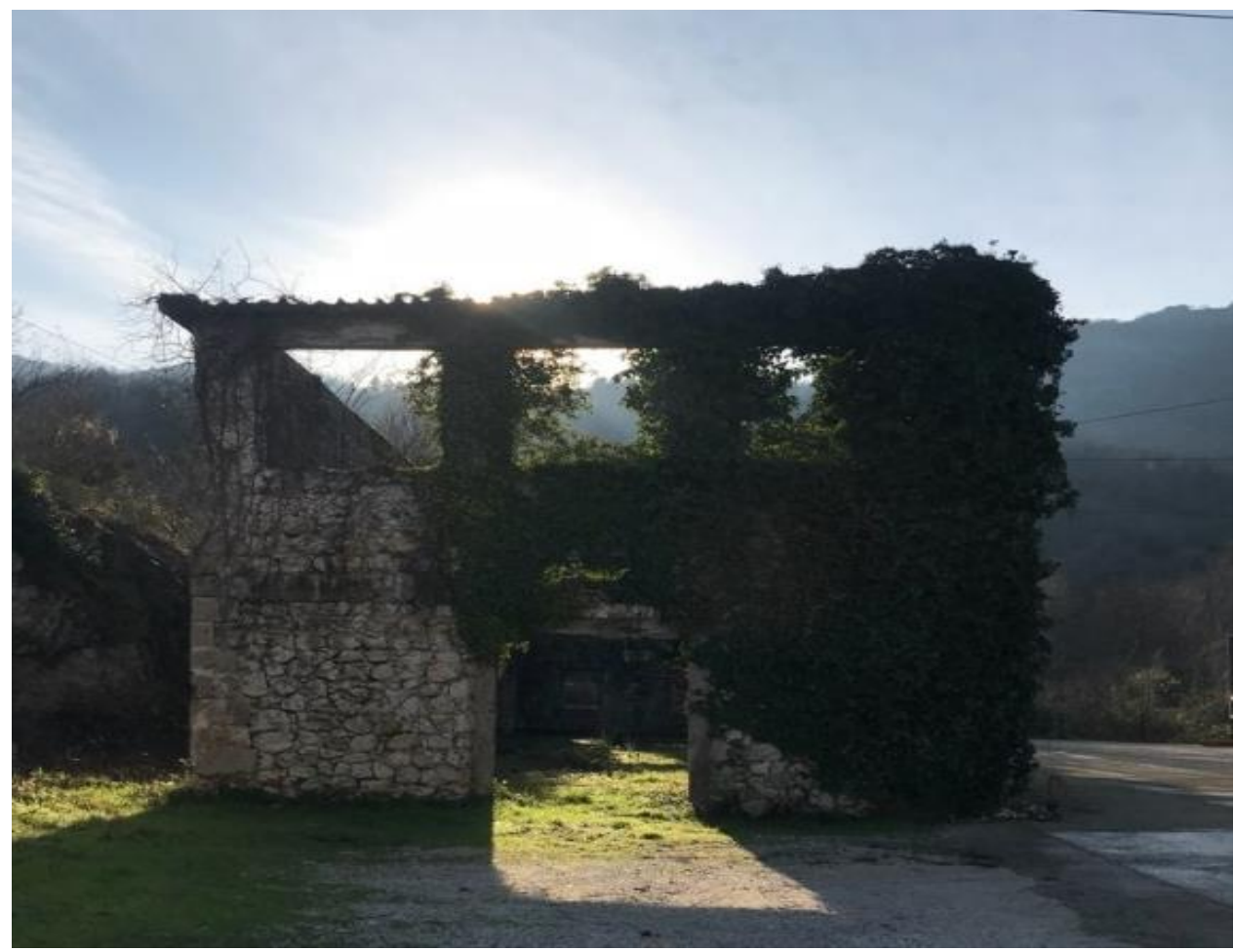

Figure 25. Abandoned building near village Godinje 
It is possible to outline certain principles in the process of construction the rules of the act of creation in vernacular architecture, which are recognized in both of these examples:

(1) Functionality; (2) Simplicity;

(3) Cost-effectiveness; (4) Bioclimate;

(5) Aesthetics; (6) Humanity

Namely, modesty of all the architectural elements of the house in relation to the nature, following the aforementioned principles, had, as a result, a functional housing architecture based on collectivistic. Man knew, without prior knowledge, that he was responding to the challenges of nature, that is, he was adjusting his process of construction to the processes of evolution. Today is a moment of stagnation, which gravitates toward disappearance. Abandoned and un-valorised works of vernacular architecture exist, but only as ruins occupied by nature, with no man. They are on the earth and exist in landscapes as their integral part and as a reminder of the winning concepts of designing within natural entities.

\section{References}

Dudic, N. (1967): The village of Brca near Bar. TI= Urbanism Architecture - Journal of Architecture, Urbanism, Applied Arts and Industrial Design, vol. 8, No. 48, pp. 4650.

Fikfak, A., Popovic, G.S. \& Kosanovic, S. (2015): Settlement patterns in an agrarian landscape -principles of classification in Goriska Brda, Slovenia. Agriculture and Forestry, 61 (4), 319-335.

Fikfak, A., Spalevic, V., Kosanovic, S., Popovic, S. G., Djurovic, M., \& Konjar, M. (2017): Land Use Development of Vineyards in Goriska Brda, Slovenia. Notulae Botanicae Horti Agrobotanici Cluj-Napoca, 45(2), 611-622.

Kosanovic, S., Fikfak, A., and Popovic, S. (2016): Agrarian landscape between transition and sustainability - Gracanica area case study. Agriculture and Forestry, 62 (2): 227-24.

Kujundzic, K. \& Stamatovic Vuckovic, S. (2019): Cultural landscape devastation as a consequence of poor Sustainable Urban Development Practice Case study: Kostanjica, Boka Bay, Montenegro. Contemporary Urban Affairs, 3(1): 121- 131.

Le Corbusier (2008): Journey to the East, Loznica, Karpos

Le Corbusier (2009): Focus, No 1, Summer, London Percy Humphries\&Co, 1938, pp.512. In Bojovic, P. \& Djokic, V. eds. The theory of architecture and urbanism, pp. 190-195, Beograd, Faculty of Architecture

Ljeskovic Mitrovic, S. (2014): Rulebook for Landscape Planning, Podgorica, Montenegro: Ministry of Sustainable Development and Tourism. (available at http://www.mrt.gov.me/ministarstvo)

Ministry of Sustainable Development and Tourism. (2016): National Strategy of Sustainable Development of Montenegro until 2030. Podgorica, Montenegro (available at http://www.mrt.gov.me/odrzivi/165045/Obavjestenje-Nacionalnastrategija-odrzivog-razvoja-do-2030-godine.html) 
NGO Expeditio. (2004): Publication of an architectural workshop in the village of Godinje, Skadar Lake (available at https://issuu.com/expeditiokotor/docs/godinjearhitektonska-radionica)

Norberg-Shulc, Christian (2009): The phenomenon of Place. In Bojovic, P. \& Djokic, V. eds. The theory of architecture and urbanism, pp. 260-273, Beograd, Faculty of Architecture

Pađan, Z. (2005): Architecture of Nature, Zagreb, Skolska knjiga

Palang, H., Printsmann, A., Konkoly Gyoro, E., Urbanc, M., Skowronek, E. \& Woloszyn, W. (2006): The forgotten rural landscape of Central and Eastern Europe. Landscape Ecology, 21, 347-357.

Parsipour, H., Popovic, S., Behzadfar, M., Skataric, G., Spalevic, V. (2019): Cities expansion and land use changes of agricultural and garden lands in peri-urban villages (case study: Bojnurd). Agriculture and Forestry, 65(3): 173-187.

Perovic, P. (2005): Architecture as crystallization of landscape and human consciousness. In Vuksanovic, D. eds. Traditional architecture of Montenegro - experiences, lessons, vision, pp. 31-38. Podgorica, University of Montenegro, Faculty of Civil Engineering

Radovic, D. (2005): The future of the architectural heritage- the possibilities of returning the principles of vernacular architecture. In Vuksanovic, D. eds. Traditional architecture of Montenegro- experiences, lessons, vision, pp. 103-110. Podgorica, University of Montenegro, Faculty of Civil Engineering

Redman, C. (2008): Introduction. In: C. Redman \& D. Foster, eds. Agrarian landscapes in transition: comparisons of long-term ecological and cultural change, pp. 3-15. Oxford University Pres

Rudofsky, B. (1964): Architecture without architects, New York, Museum of Modern Art

Stamatovic Vuckovic, S. (2018): Zero spaces. In: Cattaneo, E., Radovic Jelovac, S. eds. Emerging Resilience - Reimagining voids through sharing values. Wo/Man under the Umbrella. Ministry of Sustainable Development and Tourism of Montenegro

Van Der Lan, Dom Hans (2009): Nature and architecture. In Bojovic, P. \& Djokic, V. eds. The theory of architecture and urbanism, pp. 129-134, Beograd, Faculty of Architecture.

Vitruvius Pollio, M. (2009): On architecture, Beograd, Zavod za udzbenike i Dosije studio

Vuksanovic D. (2005): Traditional architecture of Montenegro - experiences, lessons, vision, Podgorica, Faculty of Civil Engineering.

Vuksanovic, D. (1998): Traditional architecture of Montenegro and bioclimatism, Beograd, Zaduzbina Andrejevic. 